\title{
Influence of mouthguards on masticatory muscles - surface electromyography-assisted study
}

\author{
Wpływ zastosowania ochraniaczy wewnątrzustnych na mięśnie żucia \\ - badanie z użyciem bezprzewodowej elektromiografii powierzchniowej
}

\section{Katarzyna Mańka-Malara, Dominika Gawlak}

Department of Prosthetic Dentistry, Medical University of Warsaw

Katedra Protetyki Stomatologicznej, Warszawski Uniwersytet Medyczny

Head: prof. dr hab. n. med. Jolanta Kostrzewa-Janicka

KEY WORDS:

electromyography, mouthguards, stomatognathic system

\section{Summary}

Introduction. Mouthguards constitute an important element in the prevention of the effects of head and mouth injuries. The type of appliance to be used remains the responsibility of the athlete, and the choice and frequency of the device depends on personal preferences and previous experience. The long-term use of protective splints, in conditions of increased physical and mental load, can influence the whole stomatognathic system.

Aim of the study. To evaluate the impact of mouthguards on the masticatory muscles.

Material and methods. In the course of the study, thirty athletes tested a total of 120 mouthguards. Each one was provided with two customized mouthguards - made of Impak material (Vernon - Benshoff Comp., USA) and Corflex Orthodontic (Pressing Dental, Italy) and two standard mouthguards - Porida (Combat Gear, Pakistan, India), and Shock Doctor Gel Max Strapless (Shock Doctor, Inc., USA). Surface electromyography examination of the masticatory muscles was carried out using a wireless system. The trials, including control and tested protectors, were performed in random
HASŁA INDEKSOWE:

elektromiografia, ochraniacze wewnątrzustne, układ stomatognatyczny

\section{Streszczenie}

Wprowadzenie. Ochraniacze wewnatrznustne stanowia istotny element profilaktyki skutków urazów w obrębie głowy $i$ jamy ustnej. Rodzaj stosowanego uzupetnienia pozostaje $w$ gestii sportowca, a jego wybór i częstotliwość wymiany uzależniony jest od jego osobistych preferencji i wcześniejszych doświadczeń. Wielogodzinne stosowanie szyn ochronnych przez zawodników trenujacych profesjonalnie, $w$ warunkach zwiększonego obciązenia fizycznego i psychicznego całego organizmu, oznacza możliwość ich oddziaływania na caly uktad stomatognatyczny.

Cel pracy. Ocena wptywu zastosowania ochraniaczy wewnątrzustnych na mięśnie żucia.

Material i metody. $W$ badaniu klinicznym wzięto udziat 30 sportowców, którzy przetestowali tacznie 120 ochraniaczy wewnatrzustnych. Każdy z badanych zostat zaopatrzony w 2 ochraniacze indywidualne - z materiatu Impak (Vernon - Benshoff Comp., USA) i Corflex Orthodontic (Pressing Dental, Włochy) i 2 standardowe - Porida (Combat Gear, Pakistan, Indie) oraz Shock Doctor Gel Max Strapless (Shock Doctor, Inc., USA). Badanie elektromiografii powierzchniowej mięśni żucia $w$ czasie treningu z ochraniaczem 

examination were subjected to statistical analysis with repeated measurements, where the variable was muscle tension, the independent variable, the mouthguard, and the covariant the gender.

Results. The type of protective splint and the gender did not affect the measured variable. The application of a mouthguard had no impact on the masticatory muscles tension.

Conclusions. 1. Mouthguard users should be informed that its application does not increase the masticatory muscles tension. 2. Mouthguards can be used during both training and sports competitions. order. The results of the electromyographic

przeprowadzono za pomoca bezprzewodowego systemu. Wykonywano w losowej kolejności próbę bez uzupetnienia, próby $w$ testowanych szynach ochronnych oraz próbę kontrolna. Wyniki badania elektromiograficznego zostaty poddane analizie statystycznej z powtórzonymi pomiarami, gdzie zmienna byto napięcie mięśniowe, zmienna niezależna ochraniacz a kowariantem pleć.

Wyniki. Typ ochraniacza ani uwzględniona pleć badanych nie miaty wplywu na mierzona zmienna. Zastosowanie ochraniaczy nie powodowato zmiany napięcia mięśni żucia.

Wnioski. 1. Użytkownicy wewnatrzustnych szyn ochronnych powinni być informowani, iz ich zastosowanie nie powoduje zwiększenia napięcia mięśni żucia. 2. Ochraniacze wewnątrzustne moga być stosowane zarówno podczas treningów, jak i zawodów sportowych.

\section{Wstęp}

Mouthguards are a type of occlusal splints made of elastic polymeric materials. ${ }^{1-3}$ They reduce the risk of damage to the teeth, soft tissues, and prevent jaw fractures by absorbing and dissipating the forces. The most commonly used protective appliances are standard mouthguards - formed by the user in the oral cavity after being plasticized in hot water - and customized guards prepared in cooperation with the technician on the basis of impressions taken by dentists. ${ }^{4,5}$ The correct design of a standard mouthguard is possible only at a specific temperature, at the moment of the plasticity of the material. In the case of difficulties, reshaping can be performed, but this may result in inaccuracies inducing occlusal problems. In addition, there are discrepancies in the range of temperatures indicated by manufacturers and those optimal for obtaining the most favourable properties of the material, which may cause thermal damage to the oral mucosa, insufficient retention, or inappropriate molecular structure
Ochraniacze wewnątrzustne są rodzajem szyn okluzyjnych wykonywanych z elastycznych materiałów polimerowych. ${ }^{1-3}$ Zmniejszają ryzyko uszkodzeń zębów i tkanek miękkich oraz absorbując i rozpraszając siłę uderzenia, obniżają ryzyko wystąpienia złamania w obrębie kości szczęki i żuchwy. Do najczęściej stosowanych szyn ochronnych należą ochraniacze standardowe - formowane $\mathrm{w}$ jamie ustnej po uplastycznieniu w gorącej wodzie przez użytkownika oraz indywidualne - wykonywane we współpracy z pracownią techniczną na podstawie wycisków pobranych przez lekarza dentystę. ${ }^{4,5}$ Właściwe ukształtowanie standardowej szyny możliwe jest wyłącznie w ściśle określonej temperaturze, w momencie plastyczności materiału. W przypadku wystąpienia trudności próbę formowania można powtórzyć, ale grozi to niedokładnościami indukującymi zaburzenia zwarciowe. Dodatkowo w zakresie temperatur wskazywanych przez producentów 
of the final mouthguard. ${ }^{6}$ In the production of customized intra-oral protectors, the vacuumforming technique using ethylene-vinyl acetate copolymer, traditional polymerization, and thermal injection are used. ${ }^{7,8}$ By pressing the material in the polymerization can or injecting under high pressure, precision adherence of the splint is achieved, and the dimensions of the final appliance are consistent with the designed ones. Additionally, such prepared mouthguards are positively evaluated by the users and doctors, having appropriate damping properties. ${ }^{7,9,10}$ The inaccurate adjustment of the protective splint usually causes the need of clenching the teeth in order the keep it in place - insufficient retention of "boil and bite" guards are reported by $42 \%$ of users. ${ }^{11}$ Standard mouthguards are characterized by less favourable functional and mechanical properties than those custom-made. 7-10,12-15

A properly constructed protective splint should provide an optimal level of protection against the effect of injuries while maintaining favourable performance parameters. Moreover, an intra-oral guard must not exert any adverse effect on the stomatognathic system. The conducted research aimed to assess the influence of mouthguard application on the masticatory muscles.

\section{Material and methods}

The study involved thirty athletes, training disciplines which involve mouthguards application, testing a total of 120 intra-oral splints. The proportion of women to men was equal. All the participants were familiar with the planned course of the study and expressed their agreement to participate. A thorough general and specialist interview, as well as dental examination, was conducted for each patient. Among the exclusion criteria for participation were systemic diseases, missing teeth, stomatognathic system complaints, i optymalnych dla uzyskania najkorzystniejszych właściwości materiału, istnieją duże rozbieżności, co może być przyczyną termicznych uszkodzeń błony śluzowej, niewystarczającej retencji lub niewłaściwej struktury molekularnej gotowej szyny ochronnej. ${ }^{6}$ W wykonawstwie indywidualnych ochraniaczy wewnątrzustnych, wykorzystywana jest technika formowania wgłębnego z kopolimeru etylenu i octanu winylu (EVA), metoda tradycyjnej polimeryzacji $\mathrm{w}$ puszce i metoda wtrysku termicznego. ${ }^{7,8}$ Poprzez prasowanie materiału w puszce polimeryzacyjnej lub wtłaczanie go pod dużym ciśnieniem uzyskuje się dokładne przyleganie szyny do podłoża, a wymiary gotowego uzupełnienia zgodne są z zaprojektowanymi. Dodatkowo ochraniacze wykonane $\mathrm{w}$ ten sposób są pozytywnie ocenianie przez użytkowników i lekarzy oraz mają odpowiednie własności tłumienia energii uderzenia. ${ }^{7,9,10}$ Niedokładne dostosowanie szyny ochronnej powoduje zwykle konieczność zaciskania zębów w celu utrzymania jej na podłożu - nieprawidłowa retencja uzupełnień typu „boil and bite” zgłaszana jest przez $42 \%$ użytkowników. ${ }^{11}$ Standardowe ochraniacze charakteryzują się mniej korzystnymi właściwościami użytkowymi i mechanicznymi niż wykonane indywidualnie. ${ }^{7-10,12-15}$

Prawidłowo skonstruowany ochraniacz wewnątrzustny powinien zapewniać optymalny poziom ochrony przed skutkami urazów przy zachowaniu korzystnych parametrów użytkowych. Stosowana szyna ochronna nie może również niekorzystnie oddziaływać na układ stomatognatyczny. Celem przeprowadzonych badań była ocena wpływu zastosowania ochraniaczy wewnątrzustnych na mięśnie żucia.

\section{Material i metody}

W badaniu uczestniczyło 30 sportowców zawodniczo trenujących dyscypliny, w których zastosowanie mają ochraniacze 
teeth clenching or grinding, palpative pain of masticatory muscles, the asymmetric opening of the mouth, acoustic symptoms from the temporomandibular joint or clicking, and poor oral hygiene.

The study included 60 customized and 60 standard mouthguards. For each patient, two customized splints were prepared - using the Impak (Vernon - Benshoff Comp., USA) and Corflex Orthodontic (Pressing Dental, Italy) material. To obtain appliances made of Impak, the pattern of the splint made of silicone was placed in the flask. After the gypsum had set, the silicon material was removed and replaced by Impak, mixed in the ratio of powder to liquid $1.3: 1$. The correct composition is necessary to achieve optimal elasticity of the mouthguard -if a larger volume of fluid were used, the final splint after polymerization would be more flexible. After pressing the flask and polymerizing according to producers' recommendations - for 5 hours at the temperature of about $74^{\circ} \mathrm{C}$ - the appliance was removed from the flask, cleaned, trimmed, and polished using pumice and water.

In order to prepare Corflex Orthodontic mouthguard, the same silicone pattern was placed in the flask, which was then filled with gypsum leaving the injection channel. After setting, the silicone was removed and Corflex Orthodontic was thermally injected in $\mathrm{Mg}$ Newpress (Quattro Ti, KW 700, Italy), after heating to the temperature recommended by the manufacturer $\left(165^{\circ} \mathrm{C}\right)$ under the pressure of 4 Bars. The shrinkage during curing was compensated by adding more material from the cartridge. After complete cooling, the finished custom-made mouthguard was trimmed and polished.

Final appliances were assessed during the visit, when they were given to the users, and during the control visit. The correctness of performance, the coverage of dental arches, surface formation, retention, ease of insertion and relation of the maxilla to the mandible in wewnątrzustne, testując łącznie 120 ochraniaczy. Liczba kobiet i mężczyzn była równa. Wszyscy uczestnicy zapoznali się z planowanym przebiegiem badania i wyrazili zgodę na wzięcie w nim udziału. U każdego badanego przeprowadzono dokładny wywiad ogólny i specjalistyczny oraz wykonano badanie stomatologiczne. Wśród kryteriów wykluczających udział w badaniu były choroby ogólne, braki zębowe, dolegliwości ze strony układu stomatognatycznego, zgłaszane zaciskanie lub zgrzytanie zębami, kliniczne objawy bruksizmu, bolesność palpacyjna mięśni żucia, niesymetryczny tor odwodzenia, objawy akustyczne ze strony stawu skroniowo-żuchwowego lub przeskakiwanie oraz zły stan higieny jamy ustnej.

W badaniu uwzględniono 60 ochraniaczy indywidualnych i 60 standardowych. Dla każdego pacjenta wykonano dwa ochraniacze indywidualne $-\mathrm{z}$ materiału Impak (Vernon - Benshoff Comp., USA) oraz Corflex Orthodontic (Pressing Dental, Włochy). W celu otrzymania szyn ochronnych z materiału Impak wzorzec ochraniacza wykonany z silikonu umieszczano w puszce polimeryzacyjnej. Po związaniu gipsu materiał silikonowy usuwano, a w jego miejscu umieszczano materiał Impak, zmieszany w proporcji 1,3:1 proszku i płynu. Właściwy skład jest niezbędny w celu uzyskania optymalnej elastyczności gotowej szyny - w przypadku zastosowania większej objętości płynu otrzymany ochraniacz jest bardziej elastyczny po polimeryzacji. Po sprasowaniu i polimeryzacji według zaleceń producenta - przez 5 godzin w temperaturze około $74^{\circ} \mathrm{C}$ - ochraniacz uwalniano z puszki, oczyszczano, opracowywano na mokro z zastosowaniem pumeksu i polerowano w pracowni techniki dentystycznej.

W celu wykonania ochraniacza $\mathrm{z}$ materiału Corflex Orthodontic, ten sam silikonowy wzorzec szyny ochronnej 


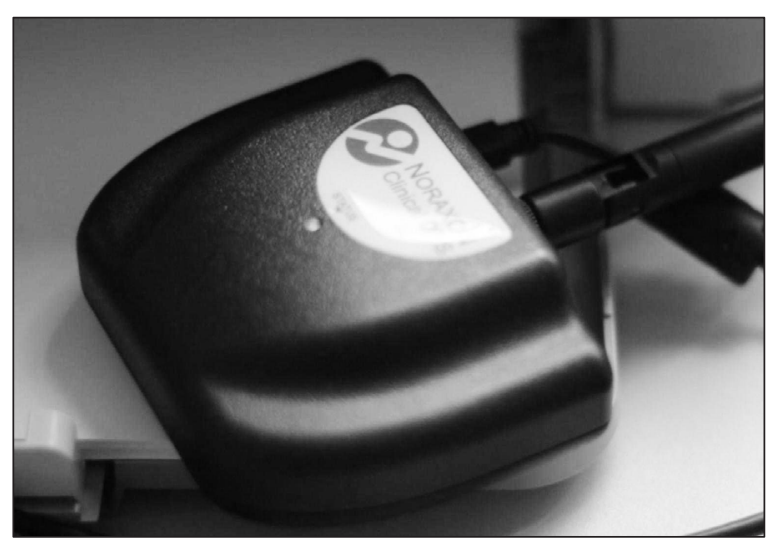

Fig. 1. The receiver of the Noraxon Clinical DTS surface electromyography system.

Ryc. 1. Odbiornik systemu elektromiografii powierzchniowej Noraxon Clinical DTS.

the presence of mouthguard in the oral cavity were verified.

For the purpose of the study, the participants also received two types of standard mouthguards ("boil and bite" type), which they prepared for use under the supervision of the dentist, according to manufacturers' instructions. They were: Porida (Combat Gear, Pakistan, Indie) and Shock Doctor Gel Max Strapless (Shock Doctor, Inc., USA). All splints were used during trainings in order to eliminate any pain caused by excessive pressure on the mucosa.

After all mouthguards were handed to the patients, the surface electromyography analysis was performed following control visits, and the adaptation period. The 4-channel system for surface electromyography was used - Noraxon Clinical DTS (Direct Transmission System), that transmits data directly from the sEMG to the small USB receiver (Fig. 1). Direct data transmission, thanks to the elimination of cable connections between the electrodes and the amplifier, allowed carrying out the analysis during movement - under the conditions corresponding to the actual use of intraoral protectors. The measurement frequency was $100 \mathrm{~Hz}$ (RMS EMG Waveforms). The electrodes were applied to clean, dry skin (two umieszczany był w puszce, wypełnianej W następnej kolejności gipsem z pozostawieniem kanału wlewowego. Po związaniu gipsu usuwano silikon, a materiał Corflex Orthodontic wprowadzano techniką wtrysku termicznego w urządzeniu Mg-Newpress (Quattro Ti, KW 700, Włochy) po podgrzaniu do temperatury zaleconej przez producenta $\left(165^{\circ} \mathrm{C}\right)$ i pod ciśnieniem 4 Barów. Skurcz powstający w trakcie utwardzania materiału rekompensowany był poprzez dodawanie go z naboju. Przygotowane ochraniacze oceniano podczas wizyty na której były oddawane do użytkowania oraz podczas wizyty kontrolnej. Weryfikowano prawidłowość ich wykonania, pokrycie łuków zębowych, ukształtowanie powierzchni, retencję, łatwość wprowadzania oraz relację żuchwy w stosunku do szczęki po umieszczeniu szyny ochronnej w jamie ustnej.

W celu przeprowadzenia badania zawodnicy otrzymali również dwa rodzaje ochraniaczy standardowych (typu „boil and bite”), które przygotowywali do użytkowania samodzielnie pod kontrolą lekarza dentysty, zgodnie z załączoną przez producenta instrukcją. Były to: Porida (Combat Gear, Pakistan, Indie) oraz Shock Doctor Gel Max Strapless (Shock Doctor, Inc., USA). Wszystkie szyny były użytt kowane podczas treningów w celu wcześniejszego wyeliminowania ewentualnych dolegliwości bólowych, wynikających z nadmiernego ucisku na błonę śluzową.

Po oddaniu wszystkich ochraniaczy do użytkowania, wizytach kontrolnych i okresie adaptacji przeprowadzono badanie elektromiografii powierzchniowej. Wykorzystano w nim bezprzewodowy, 4 kanałowy, system do treningu i rejestracji elektromiografii powierzchniowej Noraxon Clinical DTS (Direct Transmission System - System Bezpośredniej Transmisji), który przekazuje dane bezpośrednio z sEMG do małego odbiornika USB (ryc. 1). Bezpośrednia transmisja danych dzięki elimi- 


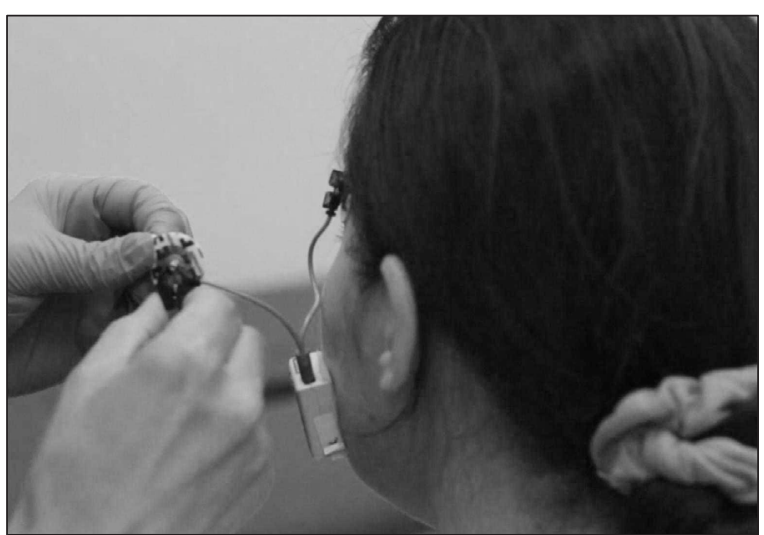

Fig. 2. The transmitter of the Noraxon Clinical DTS surface electromyography system.

Ryc 2. Nadajnik systemu elektromiografii powierzchniowej Noraxon Clinical DTS.

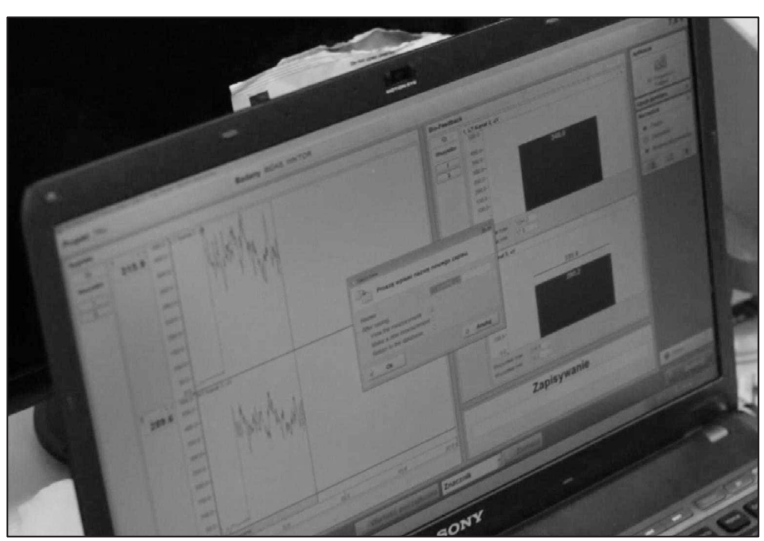

Fig. 3. Registration of muscle activity in the program. Ryc 3. Rejestracja aktywności mięśni w programie.

on each side), recording tension from the area of the masseter and temporal muscles, and two EMG transmitters, weighing only 12 grams, were positioned on both sides of the athlete's face (Fig. 2). The location of the sensors was not changed during the study. Initially, calibration was performed by registering muscle activity during the maximum clenching of dental arches. Then, in each trial, the athletes were performing dynamic blows with their hands, and the released activity of the masticatory muscles was recorded by the device (Fig. 3). Measurements were made in random order with and without a mouthguard in the oral cavity. Between each go, the participants had a break. nacji połączeń kablowych między elektrodami a wzmacniaczem, pozwoliła na wykonanie analizy w czasie ruchu - w warunkach odpowiadających rzeczywistemu użytkowaniu ochraniaczy wewnątrzustnych. Częstotliwość pomiarów wynosiła $100 \mathrm{~Hz}$ (RMS EMG Waveforms). Elektrody przyklejone na oczyszczoną i suchą skórę (po dwie z każdej strony), rejestrujące napięcie z okolicy mięśnia żwacza i skroniowego oraz dwa, ważące jedynie 12 gramów, nadajniki sEMG były zlokalizowane po obu stronach twarzy sportowca (ryc. 2). Umiejscowienie czujników nie było zmieniane w czasie badania. Na wstępie wykonywano kalibrację poprzez rejestrację aktywności mięśni w czasie maksymalnego zwarcia łuków zębowych. Następnie w każdej próbie zawodnicy wykonywali przez dziesięć sekund dynamiczne uderzenia rękami, a wyzwolona w tym czasie aktywność mięśni żucia rejestrowana była przez urządzenie (ryc. 3). W losowej kolejności przeprowadzono pomiary z wprowadzonym do jamy ustnej ochraniaczem i bez niego. Pomiędzy każdą próbą zawodnicy mieli czas odpoczynku.

Za pomocą Noraxon Clinical DTS dokonywano wstępnej obróbki danych za pomocą algorytmu RMS (średniej kwadratowej) o stałym oknie czasowym $100 \mathrm{~ms}$, dzięki czemu otrzymywany sygnał był od razu oczyszczony i łatwiejszy do odczytu.

Wyniki badania zostały poddane analizie statystycznej za pomocą programu SPSS w wersji 22. Wykonano test ACOVA (analiza kowariancji) z powtórzonymi pomiarami, gdzie zmienną było napięcie mięśniowe $\mathrm{z}$ badania elektromiograficznego, zmienną niezależną ochraniacz, a kowariantem płeć.

\section{Wyniki}

Raport elektromiograficzny opracowano w programie MR3 myoMuscle. Tworzone wzorce średniej aktywacji pozwoliły na ocenę 
Ta b le 1. Electromyographic report

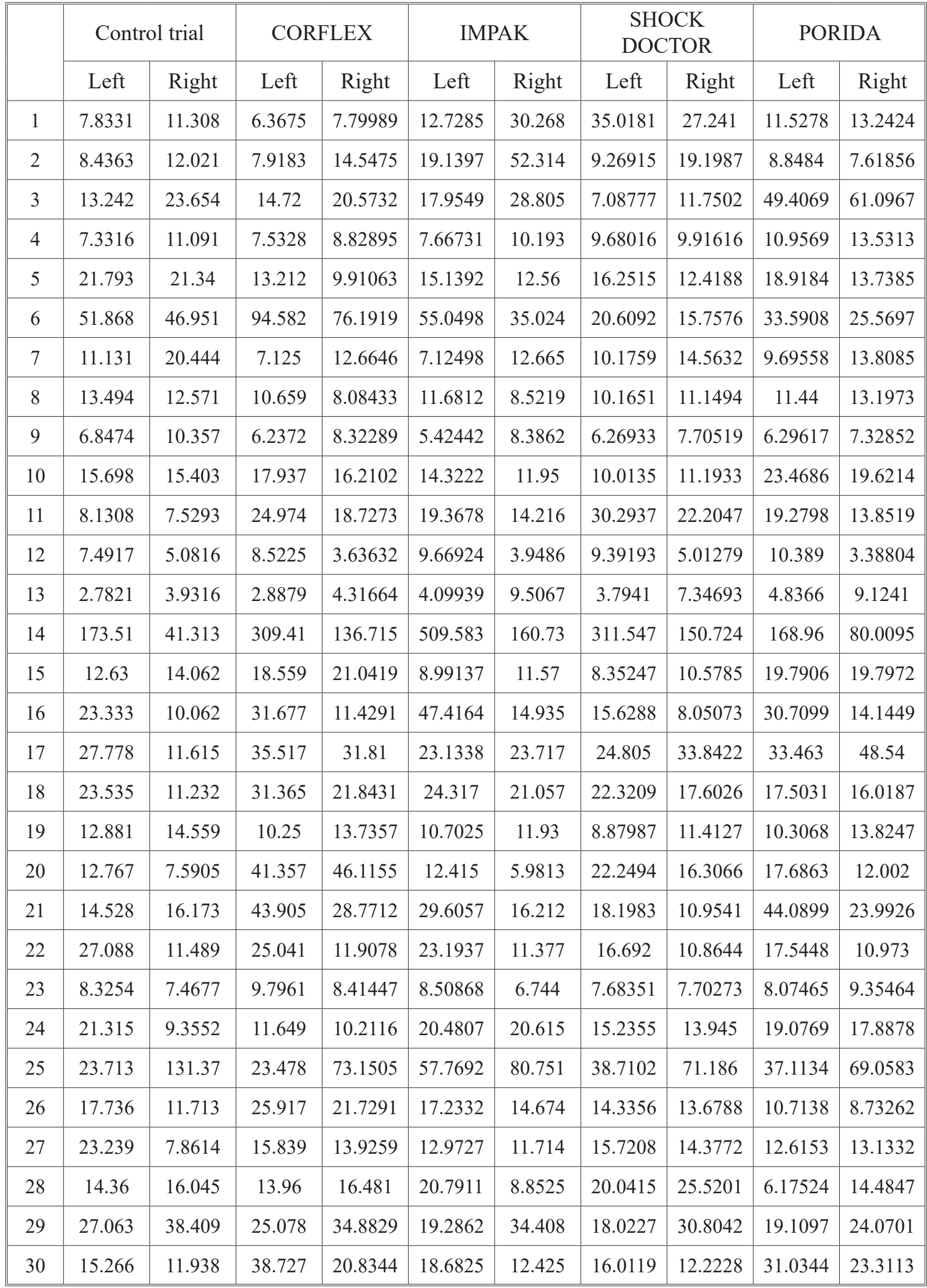


With Noraxon Clinical DTS, the data were initially preprocessed using the RMS algorithm (mean square) with a fixed time window of 100 $\mathrm{ms}$, making the received signal immediately clear and easy to read.

The results of the study were statistically analyzed using SPSS version 22. The ANCOVA test (covariance analysis) with repeated measurements wasperformed, wherethe variable was muscle tension from the electromyographic examination, the independent variable was the type of mouthguards, and the covariant was gender.

\section{Results}

The electromyographic report was developed in the MR3 myoMuscle program. The created patterns of average activation allowed the assessment of averaged and time-normalized sEMG pattern. In each test, the mean voltage obtained from the transmitter was grouped according to the tested mouthguard (Tab. 1).

The application of mouthguards during trials did not cause the increase of masticatory muscles tension. There were no statistically important differences noted, regardless of the type of the protective splint, or the gender of attendees. The results of one person ( $\mathrm{nr} 14)$, very different from the average measurements, were excluded from the analysis. Post-hoc tests, not accounting for the type of mouthguard, allowed concluding that there were differences between two pairs of guards on the verge of significance - the standard Shock doctor splint was close to being different from the customized mouthguards made of Corflex Orthodontic and Impak material.

\section{Discussion}

Non-invasive studies, such as surface electromyography, allow monitoring the impact of the appliance on the user's health - in the uśrednionego i znormalizowanego czasowo wzorca przebiegu sEMG. W każdej próbie średnie napięcie uzyskiwane z nadajnika danej strony pogrupowano według badanych ochraniaczy (tab. 1).

Zastosowanie ochraniaczy wewnątrzustnych w czasie prób nie powodowało zwiększenia napięcia mięśni. Nie odnotowano istotnych statystycznie różnic niezależnie od typu ochraniacza, jak również płci badanych. Wyniki jednej osoby (badany nr 14) bardzo odbiegającej od przeciętnych pomiarów, zostały wyłączone $\mathrm{z}$ analiz. Testy post-hoc, po uwzględnieniu, że typ ochraniacza nie ma znaczenia, pozwoliły na stwierdzenie, że na granicy istotności były różnice pomiędzy dwiema parami ochraniaczy - standardowa szyna Shock Doctor była bliska odróżnienia się od ochraniaczy indywidualnych z materiału Corflex Orthodontic i Impak.

\section{Dyskusja}

Nieinwazyjne badania, takie jak elektromiografia powierzchniowa, pozwalają na monitorowanie wpływu stosowanego uzupełnienia na zdrowie jego użytkownika $\mathrm{w}$ przypadku opisywanego $\mathrm{w}$ obecnej pracy badania - w czasie ruchu i treningu z ochraniaczem wewnątrzustnym. Badanie elektromiograficzne (EMG), polega na pomiarze sygnału elektrycznego wytworzonego przez mięsień w trakcie jego skurczu, a także ocenie czasu trwania potencjału, jego amplitudy i kształtu. ${ }^{13}$ Poddawany ocenie jest zarówno zapis spoczynkowy jak i wysiłkowy jednostki motorycznej. Podczas umiarkowanego wysiłku wykonywanego przez zdrowy mięsień rejestrowane są pojedyncze potencjały jednostki ruchowej. Rejestracja pomiarów może następować w czasie aktywności mięśni lub w spoczynku. Końcowy sygnał jest wynikiem sumowania przestrzennego i czasowego potencjałów aktywnych jednostek ruchowych 
current study during movement and training with the mouthguard. Electromyographic examination (EMG) is the measurement of the electrical signal generated by the muscle during its contraction, as well as assessing the duration of its potential, its amplitude, and shape.${ }^{13}$ Both the resting and exertion records of the motor units are recorded. During the moderate effort of the healthy muscle, single potentials of the motor unit are registered. Measurements may be taken while muscles are active or at rest. The final signal is the result of spatial and temporal summation of the potentials of active motor units located in the electrode registration area. The mechanical activity of the muscle is preceded by the registration of its electrical activity - this phenomenon is called the electromechanical delay (EMD), and depends, among others, on the temperature, the muscle structure, and operating conditions. ${ }^{14,15}$ Despite these limitations, the EMG measurements characterize the mechanical activity of muscles fairly well. Elementary and global electromyography examinations are used for the research. In the elementary EMG (unit, quantitative), needle electrodes are used, and the work of individual motor units is analysed. The global EMG (surface, sEMG) examines the entire muscle. The former is much more precise (smaller amplitude of potentials is recorded) and is more selective, but it is an invasive method. The examination is associated with damage to the continuity of the patient's skin, causes discomfort and pain, increasing the tension of the examined muscle. Additionally, placing the electrode directly into the muscle causes mechanical stimulation and the formation of an electrical signal. Surface electromyography is a non-invasive method, but less accurate. Besides, muscles that are covered with bone tissue or other muscles cannot be examined. ${ }^{16,17}$

The primary application of surface electromyography is to study muscle function. In dentistry, during sEMG examination, the znajdujących się w obszarze rejestracji elektrod. Mechaniczną aktywność mięśnia poprzedza rejestracja jego aktywności elektrycznejzjawisko to nazywane jest opóźnieniem elektromechanicznym (EMD), które zależy m.in. od temperatury, struktury mięśnia i warunków jego działania. ${ }^{14,15}$ Mimo tych ograniczeń, pomiary EMG dość dobrze charakteryzują mechaniczną aktywność mięśni. Do badań wykorzystywana jest elektromiografia elementarna i globalna. W EMG elementarnej (jednostkowej, ilościowej) stosowane są elektrody igłowe, a analizie podlega praca poszczególnych jednostek motorycznych. EMG globalna (powierzchniowa, sEMG) badaniem obejmuje cały mięsień. Pierwsza jest znacznie dokładniejsza (rejestrowane są mniejsze amplitudy potencjałów) i charakteryzuje się większą selektywnością, jest jednak metodą inwazyjną. Przeprowadzenie badanie jest związane z uszkodzeniem ciągłości powłok skórnych pacjenta, powoduje dyskomfort oraz ból, zwiększając napięcie badanego mięśnia. Dodatkowo umieszczanie elektrody bezpośrednio w mięśniu powoduje mechaniczne pobudzenie wywołując powstanie impulsu elektrycznego. Elektromiografia powierzchowna jest metodą nieinwazyjną, jednak mniej dokładną. Dodatkowo, nie można zbadać mięśni położonych głęboko, które są przykryte tkanką kostną lub innymi mięśniami. ${ }^{16,17}$

Podstawowym zastosowaniem elektromiografii powierzchniowej jest badanie czynności mięśni. W stomatologii podczas badań sEMG elektrody rozmieszczane są w projekcji włókien mięśniowych mięśni skroniowych, okrężnego ust, żwaczy i podgnykowych, a pacjent wykonuje najczęściej określone czynności, takie jak żucie czy połykanie śliny. ${ }^{18-21}$ Lokalizacja elektrod, grubość tkanki skórnej i tłuszczowej w obszarze rejestracji oraz zmiana kształtu mięśnia w czasie ruchu ma wpływ na wynik pomiaru. Elektrody powinny być położone 
electrodes are placed in the projection of muscle fibers - temporal, orbicularis oris, masseter, and hyoid muscles, and the patient performs the most common specific activities, such as chewing or swallowing saliva. ${ }^{18-21}$ The location of the electrodes, the thickness of the skin and adipose tissue in the area of registration, as well as the change in the shape of muscle during movement affect the measurements. The electrodes should be placed parallel to muscle fibers, and remain in the same, repeatable position to make the test result reliable. In this study, performed during training with various types of mouthguards, the position of electrodes was the same for all trials, and the athlete had a rest period between attempts. Taking such tests on different days would be a mistake a different location of the sensor would result in the registration of activity from a different area, and thus the results would not be comparable. Trials were performed in a random sequence, different for each participant to eliminate the influence of the order.

The correlation of the recorded signal and the strength of muscle contraction varies between muscles and depends on the composition and spatial distribution of the fibers. ${ }^{21}$ Madeleine et al. ${ }^{22}$ emphasize that the choice of sEMG to determine muscle strength may not be appropriate because the amplitude of the signal increases non-linearly with the increase in muscle strength. Some researchers looking for factors related to the determination of occlusal forces report the relationship between the dimensions of bones and facial muscles such as the length of the mandible and the face, the mandibular angle at the point of the gonion, and the thickness of masseter muscle. ${ }^{23-25}$ Kostrzewa-Janicka ${ }^{26}$ showed no significant correlation between the results of bite force tests and the individual parameters of the facial part of the skull. In this research, the tension was estimated using calibration - the amplitude of the EMG signal was measured during maximal równolegle w stosunku do przebiegu włókien mięśniowych, a także znajdować się za każdym razem w tym samym, powtarzalnym miejscu, aby wynik badania był wiarygodny. W przeprowadzonym badaniu własnym aktywności mięśni w czasie treningu $\mathrm{z}$ różnego rodzajami ochraniaczami wewnątrzustnymi, położenie raz przyklejonych elektrod było jednakowe w czasie wszystkich prób, a pomiędzy nimi zawodnik miał czas odpoczynku. Przeprowadzenie takiego badania w różnych dniach wiązałoby się ze zbyt dużym błędem - inna lokalizacja czujnika skutkowałaby rejestracją aktywności z innego obszaru, a tym samym wyniki nie byłyby porównywalne. W celu wyeliminowania wpływu kolejności poszczególnych prób, wykonywane były one w losowej sekwencji, innej dla każdego uczestnika badania.

Korelacja rejestrowanego sygnału i siły skurczu mięśnia jest zróżnicowana w różnych mięśniach i zależy od kompozycji i rozkładu przestrzennego włókien. ${ }^{21}$ Madeleine i wsp. ${ }^{22}$ podkreślają, że wybór badaniasEMG do określenia siły mięśni może nie być właściwy, ponieważ amplituda sygnału rośnie nieliniowo z wzrostem siły mięśnia. Niektórzy badacze poszukujący czynników związanych z określeniem sił zgryzowych podają występowanie związku siły z wymiarami kości i mięśni twarzy - m.in.: długości żuchwy i kąta żuchwowego w punkcie gonion, długości twarzy i grubości mięśnia żwacza. ${ }^{23-25}$

Kostrzewa-Janicka ${ }^{26}$ wykazała brak istotnych zależności między wynikami badań sił zgryzowych a pojedynczymi parametrami budowy anatomicznej części twarzowej czaszki. W przeprowadzonych badaniach napięcie było szacowane z wykorzystaniem kalibracji - podczas maksymalnego skurczu mięśnia mierzono amplitudę sygnału EMG, a kolejne wyniki były porównywane względem zarejestrowanej aktywności z tego obszaru. 
contraction, and the subsequent results were compared to recorded activity from this area.

\section{Conclusions}

1. Mouthguard users should be informed that its application does not increase the masticatory muscles tension.

2. Mouthguards can be used during both training and sports competitions.

\section{Wnioski}

1. Użytkownicy wewnątrzustnych szyn ochronnych powinni być informowani, iż ich zastosowanie nie powoduje zwiększenia napięcia mięśni żucia.

2. Ochraniacze wewnątrzustne mogą być stosowane zarówno podczas treningów, jak i zawodów sportowych.

\section{References / Piśmiennictwo}

1. KnapikJ, Marshall S, Lee R, Darakjy S, Jones $S$ : Mouthguards in Sport Activities. History, Physical Properties and Injury Prevention Effectiveness. Sports Med 2007; 37: 117-144.

2. Emerich K, Nadolska-Gazda E: Dental trauma prevention and knowledge concerning dental first-aid among Polish amateur boxers. J Sci Med Sport 2013; 16: 297-301.

3. Ifkovits $T$, Kühl S, Connert T, Krastl G, Dagassan-Berndt D, Filippi A: Prevention of dental accidents in Swiss boxing clubs. Swiss Dental Journal SSO 2015; 125: 1322-1329.

4. Gawlak D, Gawor E: Postępowanie kliniczne i laboratoryjne w wykonawstwie ochraniaczy jamy ustnej stosowanych podczas uprawiania różnych dyscyplin sportowych. Mag Stomatol 2007; 9: 26-29.

5. Gawlak D, Łojszczyk R: Materiały i metody stosowane w wykonawstwie ochraniaczy jamy ustnej użytkowanych podczas uprawiania różnych dyscyplin sportowych. Stomat Współ 2010; 17: 8-15.

6. Guerard S, Barou JL, Petit J, Poisson $P$ : Characterization of mouth-formed mouthguards: Thermal performance. Dent Mater J 2014; 33: 799-804.

7. Gawlak D, Mierzwińska-Nastalska E, MańkaMalara K, Kamiński T: Assessment of custom and standard self-adapted mouthguards in terms of comfort and users subjective impressions of their protective function. Dent Traumatol 2015; 31: 113-117.

8. Bochnig MS, Oh MJ, Nagel T, Ziegler F, Brinkmann PGJ: Comparison of the shock absorption capacities of different mouthguards. Dent Traumatol 2017; 33: 205-13.

9. Mańka-Malara K, Gawlak D: Porównanie ochraniaczy wewnątrzustnych stosowanych w sportach walki. Dent Med Probl 2013; 50: 205-209.

10. Gawlak D, Mańka-Malara K, MierzwińskaNastalska E, Roman G, Kamiński T, Łuniewska $M$ : A comparison of impact force reduction by polymer materials used for mouthguard fabrication. Acta Bio 2017; 19: 89-95.

11.DeYoung AK, Robinson E, Godwin WC: Comparing comfort and wereability: custom-made vs self-adapted mouthguards: J Am Dent Assoc 1994; 125: 1112-1118.

12. Finch C, Braham R, McIntosh A, McCrory P, Wolfe $R$ : Should football players wear custom fitted mouthguards? Results from a group randomised controlled trial. Injury Prevention 2005; 11: 242-246.

13. Mills KR: The basics of electromyography. Neurol Neurosurg Psychiatry 2005; 76: 3235. 
14. Zhou S, Carey MF, Snow RJ, Lawson DL, Morrison WE: Effects of muscle fatique and temperature on electromechanical delay. Electromyogr Clin Neurophysiol 1998; 38: 67-73.

15. Gabriel DA, Boucher JP: Effects of repetitive dynamic contraction upon electromechanical delay. Eur J Appl Physiol Occup Physiol 1998; 79: 37-40.

16. Yamada Y, Yanamura K, Inoue M: Coordination of cranial motoneurons during mastication. Respi Physiol Neurobiol 2005; 147: 177-189.

17. Klasser GD, Okeson JP: The clinical usefulness of surface electromyography in the diagnosis and treatment of temporomandibular disorders. Int J Prosth 2007; 20: 24-24.

18. Ladha KG, Gill S, Gupta R, Verma M, Gupta M: An Electromyographic Analysis of Orbicularis Oris and Buccinator Muscle Activity in Patients with Complete Dentures Fabricated Using Two Neutral Zone Techniques - A Pilot Study. J Prosth 2013; 22: 566-574.

19. Frrario VF, Sforza C, Colombo A, Ciusa $A$ : An electromyographic investigation of masticatory muscles symmetry in normoocclusion subjects. J Oral Rehabil 2000; 27: 33-44.

20. Fuek K, Roumanas E, Blackwell K, Freymiller $E$ : Effect of Implant Support for Prostheses on Electromyographic Activity of Masseter Muscle and Jaw Movement in Patients After Mandibular Fibula Free Flap Reconstruction.
J Oral Maxill Impl 2014; 29: 162-170.

21. Lawrence JH, De Luca CJ: Myoelectric signal versus force relationship in different human muscles. J Appl Physiol Respirat Environ Exercise Physiol 1983; 54: 1653-1659.

22. Madeleine P, Bajaj P, Sogaard K, ArendtNielsen LL: Mechanomyography and electromyography force relationships during concentric, isometric and eccentric contractions. J Electro Kin 2000; 10: 33-45.

23. Ringqvist $M$ : Isometric bite force and its relation to dimensions of the facial skeleton. Acta Odont Scand 1973; 31: 35-42.

24. Proffit WR, Fields HW, Nixon WL: Occlusal forces in normal- and long-face adults. J Dent Res 1983; 62: 566-571.

25. Bakke M, Tuxen A, Vilmann P, Jensen BR, Vilmann A, Toft $M$ : Ultrasound image of human masseter muscle related to bite force, electromyography, facial morphology, and occlusal factors. Scand J Dent Res 1992; 100: 164-171.

26. Kostrzewa-Janicka J: Siła zgryzowa a budowa morfologiczna części twarzowej czaszki u pacjentów ze schorzeniami skroniowo-żuchwowymi. Protet Stomatol 2007; 57: 316324.

Zaakceptowano do druku: 4.03.2021 r.

Adres autorów: 02-097 Warszawa, ul. Binieckiego 6.

(C) Zarząd Główny PTS 2021. 